\title{
Identification of suitable Botryococcus braunii strains for non-destructive in situ hydrocarbon extraction
}

\author{
Christian Kleinert $^{1}$ (D) Carola Griehl $^{1}$ (D) \\ Received: 6 July 2020 / Revised and accepted: 22 November 2020 / Published online: 7 December 2020 \\ (C) The Author(s) 2020
}

\begin{abstract}
The process of milking microalgae is a promising approach to reduce the downstream costs for the production of valuable substances from microalgae by avoiding the steps of harvest, dewatering, and cell disruption of the common process chain (cultivation, harvesting, dewatering, cell disruption, extraction, purification). The green microalga Botryococcus braunii is particularly suited for this process due to its ability to produce large amounts of long-chain hydrocarbons accumulating in an extracellular matrix. The extracellular location of hydrocarbons is an enormous advantage in comparison with other microalgae that accumulate lipids in intracellular lipid bodies. At present, only a few B. braunii strains (UTEX 572, CCAP 807/2, SAG 807/ 1, FACHB 357, Bot22, and SCCAP 1761) have been examined for the process of long-term repetitive milking. In order to identify promising candidates for the milking process, twelve different $B$. braunii strains (SAG 30.81, SAG 807/1, UTEX 572, UTEX 2441, CCAP 807/2, ACOI 58, ACOI 1257, SCCAP K-1489, var. Showa, Bot22, SCCAP K-1761, and CCALA 779) were investigated in terms of growth, lipid accumulation, nutrient uptake, solvent compatibility, and extracellular hydrocarbon extractability. Based on these results, a ranking was defined in view of eligibility for non-destructive hydrocarbon extraction. Results indicate a particular potential for hydrocarbon milking for two of those twelve B. braunii strains. The strain Showa (71 out of 75 ranking points), which has not yet been examined for long-term repetitive milking, and the strain Bot 22 (64 out of 75 ranking points) seem to be the most suitable strains for the milking process. They both possess good extractant compatibility including hydrocarbon extractability as well as high biomass and lipid productivity.
\end{abstract}

Keywords Botryococcus braunii $\cdot$ Chlorophyceae $\cdot$ Milking $\cdot$ Hydrocarbons $\cdot$ Microalgae $\cdot$ Growth $\cdot$ Solvent compatibility

\section{Introduction}

Microalgae and their numerous advantages have been mentioned in several publications to date (Rosello Sastre and Posten 2010; Griehl and Bieler 2011; Santhosh et al. 2016; Deviram et al. 2020). They can play a key role in future strategies for reducing carbon dioxide emissions, nutrient removal from waste water, and could serve the health, food, aquaculture, cosmetic, and pharmaceutical industries with valuable, biological, ecological, and non-fossil compounds (Borowitzka 2013; Borowitzka and Moheimani 2013). Nevertheless, the costs of recovering valuable substances from microalgae biomass remain a major bottleneck in microalgae biotechnology. Based on the common process

Carola Griehl

carola.griehl@hs-anhalt.de

1 Competence Center Algal Biotechnology, Anhalt University of Applied Sciences, Koethen, Germany chain, biomass is harvested after cultivation, dewatered, disrupted, extracted, and purified, before the final product is obtained (Griehl et al. 2015). Here, the steps of harvesting, dewatering, and cell disruption make up 50 to $80 \%$ of the total process costs (Acién et al. 2012; Khoo et al. 2020). Due to the high costs of downstream processing, either the whole algae biomass is used or high value products such as pigments or polyunsaturated fatty acids are produced (Deviram et al. 2020).

The so-called process of milking of microalgae offers an opportunity to decrease costs of the downstream process chain by omitting the harvesting, dewatering, and cell disruption steps of the classical process chain (Frenz et al. 1989; Sim et al. 2001; Hejazi et al. 2004; Moheimani et al. 2014; Griehl et al. 2015; Jackson et al. 2020). Milking corresponds to continuous non-destructive in situ extraction of products from a growing algal culture. Therefore, microalgae cells must excrete the product actively to the surrounding media or an extracellular matrix. During the "milking" process, the excreted product is extracted from outer matrix by passing the 
culture suspension through a hydrophobic solvent which absorbs the product (Jackson et al. 2017). To improve profitability, it is intended to repeat this milking process multiple times with the same culture suspension and to maintain the cells alive for continuous production of new extractable products (Moheimani et al. 2014; Griehl et al. 2015; Jackson et al. 2019; Bhadana and Tyagi 2020). The "milking" or "non-destructive in situ extraction" combines growth and product formation with simultaneous product extraction without killing the microalgae. It is fundamentally different to the application of two-phase systems in separate downstream extraction steps.

A suitable alga for the process of milking is the colony forming green microalga Botryococcus braunii which produces a high content of extracellular long-chain hydrocarbons which constitute up to $86 \%$ of the total dry weight (Borowitzka 2018). These hydrocarbons are predominantly produced intracellularly and are actively excreted from the cells to an extracellular matrix around the cells to regulate the depth in the water column and to protect the cells from environmental influences (Metzger and Largeau 2005; Borowitzka 2018). Depending on the chemical structure of the hydrocarbons, B. braunii strains are subdivided into four races: A, B, L, and S (Fig. 1). In addition to the active excretion of hydrocarbons, the specific $\mathrm{CO}_{2}$ utilization of $B$. braunii during photosynthesis makes this alga an ideal candidate for the milking process. Compared with other plants using nearly $85 \%$ of the carbon to generate biomass and only $10 \%$ for fatty acid production, B. braunii utilizes only $45 \%$ to build biomass and nearly the same amount to produce hydrocarbons (Melis 2013). This specific feature of carbon partitioning during photosynthesis is responsible for the high hydrocarbon content during growth phase on the one hand, and for a relatively low growth rate on the other hand (Jackson et al. 2017), which makes the classical treatment of this alga not feasible (Griehl et al. 2015).

For the process of milking or in situ extraction, most research is carried out with emphasis on $B$. braunii because the product of interest is external to the cell. In addition to $B$. braunii, only a few other algae such as Dunaliella salina for $\beta$-carotene (Hejazi et al. 2004; Kleinegris et al. 2010), Nannochloropsis for lipids (Zhang et al. 2011), diatoms for high value molecules (Vinayak et al. 2015), or Haematococcus for astaxanthin (Praveenkumar et al. 2015; Samori et al. 2019) have been investigated for removal of products by in situ extraction. Compared with milking of $B$. braunii, the product of interest is located intracellularly for most other algae. Here, in situ extraction, where the desired product is extracted without complete regeneration of the cells, is carried out during cultivation.

So far, among the $B$. braunii strains investigated, only a handful have been examined for repetitive milking of hydrocarbons over a certain period of time (Table 1). In order to choose an ideal strain for treatment during the milking process, a variety of factors such as growth rate, amount of extracellular hydrocarbons, solvent, and nutrient uptake are critical factors for the feasibility of the process (Jackson et al. 2017). Growth rate of the milked strain and amount of excreted hydrocarbons must be kept as high as possible relating to the production of extracellular hydrocarbons which appears to be growth associated (Melis 2013). Extractability of extracellular hydrocarbons and resistance of the chosen strain to the solvent are also critical factors for the process of milking. In order to prevent the excreted hydrocarbons from being released into the medium, contact between the cells or the extracellular matrix of the colonies and the solvent is necessary to extract the hydrocarbons (Griehl et al. 2015). Therefore, biocompatibility of the solvent with minimal toxicity to the cells by simultaneous extraction of a maximum of hydrocarbons is essential (Moheimani et al. 2014). In terms of biocompatibility, solvents with higher chain length such as $n$-octane, dodecane and tetradecane showed highest biocompatibility with more than $90 \%$ compared with $n$-hexane with $80 \%$ biocompatibility (Jackson et al. 2017). However, the cost of solvent recovery after extraction is a critical factor for the feasibility of the entire milking process. Among the solvents already investigated, ranging from $n$-hexane, $n$-heptane, and $n$ octane to $n$-octanol, dodecane and dihexyl ether to tetradecane, the boiling point and thus the cost of recovery increase significantly (Jackson et al. 2017).

This study was designed to identify possible Botryococcus strains that are suitable for the process of milking. Twelve different strains of Botryococcus were evaluated and ranked in terms of growth, biomass and lipid production, nutrient uptake of nitrate and phosphate, solvent compatibility, and lipid extractability for the solvents $n$-hexane, $n$-heptane, and $n$-octane. Among the strains investigated, SAG 807/1, CCAP $807 / 2$, SCCAP 1761, and Bot22 have been used for the process of milking, while strains SAG 30.81, ACOI 1257, ACOI 58, UTEX 2441, UTEX 572, CCALA 779, SCCAP 1489, and Showa only been investigated for growth so far.

\section{Materials and methods}

\section{Microorganisms and growth conditions}

Twelve different strains of Botryococcus (Table 2) were cultured in BG11 medium (Rippka et al. 1979) in triplicate for the strains Showa and Bot22 and for reason of low inoculum biomass concentration in duplicate for the remaining strains. Cultivation was performed in 1.5-L bubble columns with continuous light at $100 \mu \mathrm{mol}$ photons $\mathrm{m}^{-2} \mathrm{~s}^{-1}$ (LED Panel, $80 \mathrm{~W}$, $6500 \mathrm{~K}$, daylight), at a temperature of $26^{\circ} \mathrm{C}$ and a gas flow rate of $1 \mathrm{vvm}$ enriched with $1 \% \mathrm{CO}_{2} \mathrm{v} / \mathrm{v}$. Cultivation was maintained over 21 days with a starting concentration of biomass adjusted between 0.2 to $0.3 \mathrm{~g} \mathrm{~L}^{-1}$. The sampling for biomass and nutrient uptake was carried out every second or third day. 


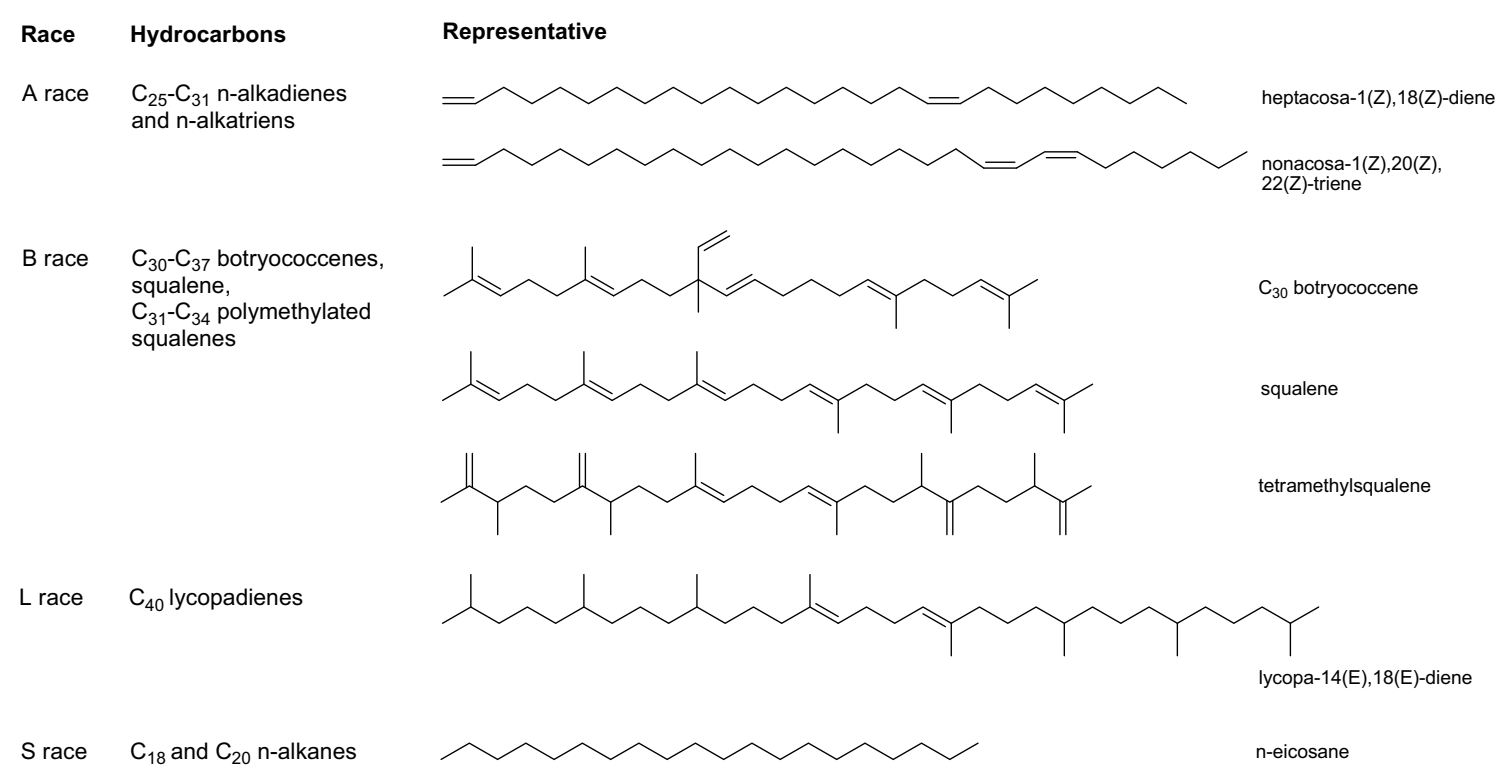

Fig. 1 Structure of hydrocarbons produced by Botryococcus races A, B, L, and S (from Griehl et al. 2015)

\section{Biomass determination}

Biomass was determined gravimetrically in triplicate and described in terms of dry weight per volume of culture $\left(\mathrm{g}_{\mathrm{DW}} \mathrm{L}^{-1}\right)$. The DW measurement was carried out by filtration of algal suspension through pre-weighed 24-mm glass fiber filters (VWR 693). Biomass containing filters were rinsed three times with ultrapure water to remove residual salts of the culture medium. Washed filters were dried at $104{ }^{\circ} \mathrm{C}$ for $12 \mathrm{~h}$ and stored for $30 \mathrm{~min}$ in a desiccator before being weighed.

\section{Nutrient determination}

Nutrient uptake was measured using a Dionex ICS 1100 System equipped with an IonPac AS23 column and a CERS 500 suppressor to determine the concentration of nitrate and phosphate in the culture medium. The system was calibrated for nitrate and phosphate in the range of 1 to $100 \mathrm{mg} \mathrm{L}^{-1}$. Prior to the measurement, the algae suspension was filtered through a $0.45-\mu \mathrm{m}$ PTFE filter and the filtrate was diluted to a measurement concentration between 1 and $100 \mathrm{mg}$ nitrate.

\section{Total lipid determination}

Total amount of lipids was determined gravimetrically in triplicate on days $0,7,14$, and 21 of cultivation using a modified version of the method published by Guckert and White (1988). Prior to lipid determination, $5 \mathrm{~mL}$ of algae culture was filtered synchronously with the biomass determination using 24-mm glass fiber filters (VWR 693) and stored in a freezer at $-80{ }^{\circ} \mathrm{C}$ until use. The frozen filter was placed in a 7-mL screw-capped glass vial, and $1 \mathrm{~g}$ of sea sand (Carl Roth 8441.1) was added. Five milliliters of $n$-hexane/isopropanol 40:26.7 (v/v) were added as solvent. Samples were extracted for $30 \mathrm{~min}$ at a frequency of $30 \mathrm{~Hz}$ using a swing mill (Retsch MM200). The samples were then centrifuged at $3000 \times g$ for $5 \mathrm{~min}$, and the solvent supernatant was transferred to a $20-\mathrm{mL}$ glass vial. The remaining pellet was dissolved in $5 \mathrm{~mL}$ of solvent, and lipid extraction was carried out twice more.

Table 1 Overview of Botryococcus braunii strains used for the process of milking

\begin{tabular}{|c|c|c|c|c|c|}
\hline Strain & Race & Solvent & Days of milking & Maximum lipid yield & Reference \\
\hline UTEX 572 & A & $n$-octane & 4 & $57 \%$ & An et al. (2004) \\
\hline CCAP 807/2 & A & n-heptane & 4 (over 6 days) & $7 \mathrm{mg} \mathrm{g} \mathrm{DW}^{-1}$ day $^{-1}$ & Moheimani et al. (2013) \\
\hline SAG 807/1 & A & $n$-hexane & 30 (over 40 days) & $\begin{array}{l}1.3 \mathrm{mg} \mathrm{g} \mathrm{DW}^{-1} \text { day }^{-1} \\
2.7 \mathrm{mg} \mathrm{L}^{-1} \text { day }^{-1}\end{array}$ & Griehl et al. (2015) \\
\hline FACHB 357 & - & Tetradecane & 4 & $50 \%$ & Zhang et al. (2013) \\
\hline Bot22 & $\mathrm{B}$ & n-heptane & 16 (over 80 days) & $12 \mathrm{mg} \mathrm{L}^{-1}$ day $^{-1}$ & Moheimani et al. (2014) \\
\hline SCCAP 1761 & B & $n$-hexane & 5 & $\begin{array}{l}59 \mathrm{mg} \mathrm{g} \mathrm{DW}^{-1} \text { day }^{-1} \\
26 \mathrm{mg} \mathrm{L}^{-1} \text { day }^{-1}\end{array}$ & Griehl et al. (2015) \\
\hline
\end{tabular}


Table 2 Origin of Botryococcus strains investigated in this study

\begin{tabular}{|c|c|c|c|c|c|}
\hline Strain & Race & Number & Isolator & Origin & Source \\
\hline Botryococcus braunii & A & $\begin{array}{l}\text { SAG } \\
30.81\end{array}$ & Hegewald, E. & Laguna Huaypo, Cuzco, Peru, 1977 & $\begin{array}{l}\text { Culture Collection of Algae at Goettingen } \\
\text { University (SAG) }\end{array}$ \\
\hline Botryococcus braunii & A & $\begin{array}{l}\text { SAG } \\
807 / 1\end{array}$ & Droop, M.R. & $\begin{array}{l}\text { Madingley Brick Pits, Cambridge, } \\
\text { UK, } 1950\end{array}$ & $\begin{array}{l}\text { Culture Collection of Algae at Goettingen } \\
\text { University (SAG) }\end{array}$ \\
\hline Botryococcus braunii & $\mathrm{A}$ & $\begin{array}{l}\text { UTEX } \\
572\end{array}$ & Droop, M.R. & $\begin{array}{l}\text { Madingley Brick Pits, Cambridge, } \\
\text { UK, } 1950\end{array}$ & $\begin{array}{l}\text { Culture Collection of Algae at University } \\
\text { of Texas (UTEX) }\end{array}$ \\
\hline Botryococcus braunii & A & $\begin{array}{l}\text { UTEX } \\
2441\end{array}$ & Hegewald, E. & Laguna Huaypo, Cuzco, Peru, 1977 & $\begin{array}{l}\text { Culture Collection of Algae at University } \\
\text { of Texas (UTEX) }\end{array}$ \\
\hline Botryococcus braunii & A & $\begin{array}{l}\text { CCAP } \\
807 / 2\end{array}$ & Jaworski, G. & Grasmere, Cumbria, UK, 1984 & $\begin{array}{l}\text { Culture Collection of Algae and } \\
\text { Protozoa (CCAP) }\end{array}$ \\
\hline Botryococcus braunii & A & $\begin{array}{l}\text { ACOI } \\
58\end{array}$ & Santos, M.F. & Porto de Castanheira, Portugal, 1979 & Coimbra Collection of Algae (ACOI) \\
\hline Botryococcus braunii & A & $\begin{array}{l}\text { ACOI } \\
1257\end{array}$ & Santos, L. & $\begin{array}{l}\text { Serra da Estrela, Barragem, } \\
\text { Portugal, } 2000\end{array}$ & Coimbra Collection of Algae (ACOI) \\
\hline Botryococcus braunii & A & $\begin{array}{l}\text { SCCAP } \\
\text { K-1489 }\end{array}$ & Hansen, G. & Nieuwpoort, Belgien, 2008 & $\begin{array}{l}\text { Scandinavian Culture Collection of } \\
\text { Algae and Protozoa (SCCAP) }\end{array}$ \\
\hline Botryococcus braunii & $\mathrm{B}$ & $\begin{array}{l}\text { var. } \\
\text { Showa }\end{array}$ & Nonomura, A. M. & $\begin{array}{l}\text { Berkeley, University of } \\
\text { California, USA, } 1980\end{array}$ & University of Tokyo, Shigeru Okada \\
\hline Botryococcus braunii & $\mathrm{B}$ & Bot 22 & Kawachi, M. & Kanna, Okinawa, Japan, 2004 & University of Tsukuba, Makoto. M. Watanabe \\
\hline Botryococcus sp. & $\mathrm{B}$ & $\begin{array}{l}\text { SCCAP } \\
\text { K-1761 }\end{array}$ & Andersen, R.A. & 12 Mile Lake, Michigan, USA, 2010 & $\begin{array}{l}\text { Scandinavian Culture Collection of Algae } \\
\text { and Protozoa (SCCAP) }\end{array}$ \\
\hline Botryococcus protuberans & N/A & $\begin{array}{l}\text { CCALA } \\
779\end{array}$ & Santos, M.F. & Serra de Estrela, Portugal, 1987 & $\begin{array}{l}\text { Culture Collection of Autotrophic Organisms } \\
\text { (CCALA) }\end{array}$ \\
\hline
\end{tabular}

Supernatants were combined and evaporated to dryness using a vacuum evaporator (Hettich Combi Dancer) at $39^{\circ} \mathrm{C}$ and $300 \mathrm{rpm}$. The dried sample was redissolved in $5 \mathrm{~mL}$ of $n$ hexane and filtered through a $0.45-\mu \mathrm{m}$ PTFE filter (Restek 13-mm Syringe Filter). The filtered extract was transferred to a pre-weighed $20-\mathrm{mL}$ glass vial, evaporated to dryness, and weighed again to obtain the total amount of lipid. Dried samples were stored at $-20^{\circ} \mathrm{C}$ for further analytical testing.

\section{Biomass yield and nutrient uptake calculation}

In order to calculate the biomass yield and nutrient uptake, experimental data were fitted to the Gompertz model (Eq. 1), which has been used to describe the growth of microalgae and bacteria (Gonçalves et al. 2016). Temporal development of DW, nitrate, and phosphate were represented by $y, k$ is a factor for DW accumulation and nutrient uptake, $a$ is the amplitude, and $x_{c}$ is the center of the model. Equation 2 was used to calculate the maximum biomass productivity and nutrient uptake rate $\left(Y_{\mathrm{DW}}, U_{\mathrm{N}, \mathrm{P}}\right)$ (Tjørve and Tjørve 2017).

$y=a e^{-e^{\left(-k\left(x-x_{c}\right)\right)}}$

$P_{\mathrm{DW}}, U_{\mathrm{N}, \mathrm{P}}=\frac{a \times k}{e}$

\section{Extracellular hydrocarbon determination}

Extracellular hydrocarbon content was measured gravimetrically in triplicate using the dried biomass containing filters after biomass determination. The dried 24-mm glass fiber filters (VWR 693) were transferred to $40-\mathrm{mL}$ glass vials, $3 \mathrm{~mL} n$-hexane were added to the filter, and glass vials were closed with a screw cap. After $24 \mathrm{~h}$ at room temperature, the solvent was transferred to preweighed $20-\mathrm{mL}$ glass vials by filtration through $0.2-\mu \mathrm{m}$ PTFE filters (Restek $13 \mathrm{~mm}$ syringe filter). The filter containing $40-\mathrm{mL}$ glass vials were rinsed twice more with $3 \mathrm{~mL} n$-hexane. Supernatants were pooled and evaporated to dryness using a vacuum evaporator (Hettich Combi Dancer) at $39{ }^{\circ} \mathrm{C}$ and $300 \mathrm{rpm}$. The glass vials were weighed again to obtain the extracellular amount of hydrocarbon.

\section{Solvent compatibility screening}

Solvent compatibility of Botryococcus strains examined was determined by using three biological replicates and a method modified by Frenz et al. (1989). Twenty milliliters of algae suspension were transferred to a $30-\mathrm{mL}$ glass vial and $10 \mathrm{~mL}$ of a particular solvent ( $n$-hexane, $n$-heptane, $n$-octane) were added. The glass vial was closed and mixed at $60 \mathrm{rpm}$ for 5 or 10 min using an electrically driven wheel. Fifteen milliliters of 
the treated algal culture were transferred to a $25-\mathrm{mL}$ glass vial to measure photosynthetic activity. Solvent containing extracellular lipid was transferred to a $20-\mathrm{mL}$ pre-weighed glass vial, evaporated to dryness, and weighed again to obtain the amount of extracellular lipid. Dried samples were stored at $20{ }^{\circ} \mathrm{C}$ for further analytical testing. In comparison, untreated cultures were handled in the same way to obtain the $100 \%$ value for photosynthetic determination.

\section{Photosynthetic activity measurement}

Cell viability was determined by measuring oxygen production of three biological replicates (InLab Optiox, Mettler Toledo). Prior to the extraction process, $15 \mathrm{~mL}$ of algae suspension was transferred to a $25-\mathrm{mL}$ glass vial and dark adapted for $12 \mathrm{~h}$ overnight. After dark adaptation, the glass vial containing the algae suspension was placed on a light bench and the oxygen probe was immersed in the suspension until the air was completely displaced. The bottom of the 25mm-diameter glass vial was illuminated with $100 \mu \mathrm{mol}$ photons $\mathrm{m}^{-2} \mathrm{~s}^{-1}$ over $15 \mathrm{~min}$ and oxygen production was recorded every $30 \mathrm{~s}$. The slope of the dissolved oxygen concentration during the measurement and biomass concentration was used to calculate the oxygen production rate in $\mathrm{mg}$ DO $\mathrm{g}_{\mathrm{DW}}{ }^{-1} \mathrm{~h}^{-1}$.

\section{Statistical analysis}

Statistical analyses were carried out using SigmaPlot 12 and OriginPro 2020 with one-way ANOVA to determine differences between the strains $(P<0.05)$. For pairwise comparison of the strains, Holm-Sidak method was applied with $P<0.05$. Results have been reported as mean \pm standard deviation.

\section{Microscopic examination}

Algal samples were examined microscopically using an Olympus BX41 microscope. Photographs were taken with an Olympus XC50 camera.

\section{Ranking of strains}

In order to determine the strains most suitable for the milking process, a ranking was created based on the results of the experiments carried out. Parameters used for the ranking are shown in Table 3. Parameters of biomass productivity, lipid productivity, extracellular hydrocarbon productivity, biocompatibility with the solvent, and extractability of extracellular hydrocarbons were ranked between 1 and 10. For industrial scale production/application, parameters of minor importance such as maximum biomass yield, maximum lipid concentration, hydrocarbon concentration, and nutrient uptake of nitrate and phosphate were ranked between 1 and 5. This created a ranking of at least 10 to a maximum of 75 points. Strains with the highest score were considered the most suitable for the milking process.

\section{Results}

\section{Growth and nutrient uptake}

Results for growth and nutrient uptake of Botryococcus strains examined (Fig. 2) are displayed in Fig. 3 and Table 4. Based on culture media pre-screening with BG11, Chu13, and AF6 media (data not shown), BG11 medium was evaluated as the most suitable for growth experiments. The highest biomass concentration was measured for the strains Showa $(2.905 \pm$ $\left.0.08 \mathrm{~g} \mathrm{~L}^{-1}\right)$ and Bot22 $\left(2.634 \pm 0.10 \mathrm{~g} \mathrm{~L}^{-1}\right)$. The biomass concentration of these two strains was significantly different from the other strains (ANOVA, $F(11,14)=286.44$, $P<0.001 / \mathrm{Holm}$-Sidak, $t \geq 3.438, P<0.05$ ). Here, values obtained for Showa and Bot 22 were $92 \%$ and $74 \%$ above the biomass concentration of the subsequent strains, respectively. Lowest biomass concentration with only $25 \%$ of the Showa strain was observed for CCALA $779\left(0.73 \pm 0.01 \mathrm{~g} \mathrm{~L}^{-1}\right)$. Comparison of the maximum biomass productivity per day (Table 4) showed that highest productivities (ANOVA, $F(11,14)=13.721, P<0.001 /$ Holm-Sidak, $t \geq 4.155$, $P<0.05)$ were obtained for Showa and Bot22. The measured productivity of Showa was approximately $11 \%$ higher compared with Bot22, UTEX 2441, and SAG 30.81. With only $0.042 \pm 0.027 \mathrm{~g} \mathrm{~L}^{-1} \mathrm{day}^{-1}$ and thus $80 \%$ less than Showa, strain CCALA 779 showed the lowest maximum biomass productivity.

The measured nutrient consumption of the different strains during the growth experiment is displayed in Fig. 3 as a percentage of the initial nutrient concentration. As can be seen in Fig. 3, concentration of nitrate and phosphate in culture medium decreased for all strains during cultivation.

The final nitrate concentration measured after 21 days ranged from 45 to $85 \%$ of the initial concentration. Highest uptake to a minimum of 45 to $50 \%$ of the initial concentration was measured for UTEX 572, UTEX 2441, ACOI 1257, and Bot22. Lowest nitrate uptake with a reduction of the initial concentration to $80 \%$ of was analyzed for strains CCALA 779, SCCAP 1761, and ACOI 58. The uptake rates of nitrate (Table 4) were in the range of $17.92 \pm 1.4$ to $56.31 \pm$ $4.1 \mathrm{mg} \mathrm{L}^{-1}$ day $^{-1}$ and significantly different for all strains (ANOVA, $F(11,14)=49.458, P<0.001)$. ACOI 1257 , CCAP 807/2, UTEX 2441, and UTEX 572 required two- to threefold more nitrate compared with SCCAP 1761, CCALA 779, ACOI 58, and Showa. By calculating nitrate uptake per biomass, the strain Showa required the least amount of nitrate. The nitrate consumption per biomass of the strain Showa was 
Table 3 Parameter classification for the ranking of Botryococcus strains examined

\begin{tabular}{|c|c|c|c|c|c|c|c|c|c|c|}
\hline $\begin{array}{l}\text { Ranking } \\
\text { points }\end{array}$ & $\begin{array}{l}P_{\mathrm{DW}} \\
\left(\mathrm{g} \mathrm{L}^{-1} \mathrm{day}^{-1}\right)\end{array}$ & $\begin{array}{l}Y_{\mathrm{DW}} \\
\left(\mathrm{g} \mathrm{L}^{-1}\right)\end{array}$ & $\begin{array}{l}P_{\text {lipids }} \\
\left(\mathrm{g} \mathrm{L}^{-1} \text { day }^{-1}\right)\end{array}$ & $\begin{array}{l}C_{\text {lipids }}(\% \\
\text { DW })\end{array}$ & $\begin{array}{l}P_{\mathrm{HC}} \\
\left(\mathrm{g} \mathrm{L}^{-1} \text { day }^{-1}\right)\end{array}$ & $\begin{array}{l}C_{\mathrm{HC}}(\% \\
\mathrm{DW})\end{array}$ & $\begin{array}{l}E_{\mathrm{HC}}(\% \\
\mathrm{DW})\end{array}$ & $\begin{array}{l}\mathrm{SC}(\% \\
\mathrm{OE})\end{array}$ & $\begin{array}{l}U_{\text {nitrate }} \\
\left(\mathrm{g} \mathrm{g} \mathrm{gW}^{-1}\right)\end{array}$ & $\begin{array}{l}U_{\text {phosphate }} \\
\left(\mathrm{g}_{\mathrm{DW}}^{-1}\right)\end{array}$ \\
\hline 1 & $>0.00$ & $\geq 0.5$ & $>0.00$ & $\geq 50$ & $\geq 0.005$ & $\geq 10$ & $>0.0$ & $\geq 10$ & $\geq 0.8$ & $\geq 0.08$ \\
\hline 2 & $>0.02$ & $>1.0$ & $>0.02$ & $>60$ & $>0.010$ & $>20$ & $>0.5$ & $>20$ & $>0.6$ & $>0.06$ \\
\hline 3 & $>0.03$ & $>1.5$ & $>0.03$ & $>65$ & $>0.015$ & $>30$ & $>1.5$ & $>30$ & $>0.4$ & $>0.04$ \\
\hline 4 & $>0.04$ & $>2.0$ & $>0.04$ & $>70$ & $>0.020$ & $>40$ & $>2.0$ & $>35$ & $>0.2$ & $>0.02$ \\
\hline 5 & $>0.05$ & $>2.5$ & $>0.05$ & $>75$ & $>0.025$ & $>50$ & $>2.5$ & $>40$ & $>0.0$ & $>0.00$ \\
\hline 6 & $>0.06$ & & $>0.06$ & & $>0.030$ & & $>3.0$ & $>45$ & & \\
\hline 7 & $>0.07$ & & $>0.07$ & & $>0.035$ & & $>4.0$ & $>50$ & & \\
\hline 8 & $>0.08$ & & $>0.08$ & & $>0.040$ & & $>5.0$ & $>55$ & & \\
\hline 9 & $>0.09$ & & $>0.09$ & & $>0.045$ & & $>6.0$ & $>65$ & & \\
\hline 10 & $>0.10$ & & $>0.10$ & & $>0.050$ & & $>7.0$ & $>75$ & & \\
\hline
\end{tabular}

$80 \%$ less than the consumption of CCAP $807 / 2$, which required the most nitrate per biomass of all strains examined.

Except for Showa and SCCAP 1761, the phosphate concentration in the culture medium decreased to $0 \%$ of the initial concentration for all strains during 21 days of cultivation. After 9 days of cultivation, no phosphate was detected when looking at UTEX 572, SAG 807/1, ACOI 1257, SAG 30.81, and CCALA 779, while the other strains reached $0 \%$ phosphate on day 11 and 21 of the cultivation period. When comparing phosphate uptake rates (Table 4), highest phosphate uptake was measured for the UTEX 572 strain. Compared with this, threefold lower phosphate uptake rates were analyzed for the strains ACOI 58, Showa, CCALA 779, and SCCAP 1489. When comparing the consumption of phosphate per biomass, significant differences between the strains were visible (ANOVA, $F(11,14)=118.415, P<0.001)$. The strain UTEX 572 required the most phosphate per biomass, which was eightfold more compared with the strain Showa with $0.010 \pm 0.002 \mathrm{~g}_{\text {phosphate }} \mathrm{g}_{\mathrm{DW}}{ }^{-1}$.

\section{Lipids and extracellular hydrocarbons}

As displayed in Fig. 4, the amount of total lipids increased during batch cultivation from start of cultivation until day 21 . After 21 days, a maximum lipid concentration with over $57.66 \pm 4.4 \%$ of biomass was achieved for all strains (Table 4). The highest amount of total lipids with nearly $80 \%$ was determined for the strains SCCAP 1761 and Showa. The strains ACOI 58, SCCAP 1489, CCAP 807/2, and Bot22 also achieved high total lipid levels in the range of $58.56 \pm 1.0$ to $69 \pm 2.4 \%$ of the biomass. The lowest total lipid concentration with only $57.66 \pm 4.4 \%$ of biomass and therewith $27 \%$ below the concentration of SCCAP 1761 was analyzed for UTEX 572 and SAG 30.81. By comparing the lipid yield, the significantly highest productivity was analyzed for Showa (ANOVA, $F(11,14)=95.576 P<0.001 /$ HolmSidak, $t \geq 7.601, P<0.05)$, followed by Bot22, which was
$30 \%$ lower than Showa. Lowest lipid productivity was obtained for CCALA 779, ACOI 58, and UTEX 572.

The amount of extracellular lipids or hydrocarbons produced by the strains is an extremely important factor for the milking process. Significantly higher amounts of extracellular hydrocarbons (Table 4) compared with all other strains (ANOVA, $F(11,14)=173.591, P<0.001 /$ Holm-Sidak, $t \geq$ $3.407, P<0.05)$ were produced by the strains Bot22, Showa, and CCAP 807/2 with 51.6 $\pm 1.9,49.3 \pm 1.4$ and $39.9 \pm 1.2 \%$ of biomass concentration, respectively. These concentrations of extracellular hydrocarbons were up to $65 \%$ higher compared with the strains SAG 30.81, UTEX 572, CCALA 779, SCCAP 1489, and UTEX 2441. Hydrocarbon productivity for the strain Showa was significantly (ANOVA, $F(11,14)=173.591, P<0.001 /$ Holm-Sidak, $t \geq 6.300$, $P<0.05)$ the highest of all the strains, followed by Bot 22 with a $6 \%$ lower hydrocarbon productivity.

\section{Solvent compatibility}

As shown in Fig. 5, all solvents tested had a negative impact on oxygen production. This negative influence increased significantly during the time of contact with the solvent (ANOVA, $F(1,70)=16.6, P<0.001)$. In general, Botryococcus strains Showa, Bot22, SAG 807/1, UTEX 2441, and CCAP 807/2 showed the best solvent compatibility with an oxygen production of over $75 \%$ and $50 \%$ for a 5 -min and 10-min treatment, respectively. For the 10 min treatment, strains SAG 807/1 and Bot 22 achieved the best compatibility with an oxygen production of over $85 \%$ for $n$-octane. Already after a short contact time with the solvent, strains CCALA 779, UTEX 572, and ACOI 1257 showed little or no oxygen production. It is evident that $n$ octane had the highest biocompatibility for most strains compared with $n$-hexane and $n$-heptane. The highest negative impact of increasing the contact time to the solvent was observed for $n$-hexane. Here, the oxygen production decreased from $80.98 \pm 6.24$ to $49.57 \pm 5.89 \%$ and from $83.53 \pm 14.77$ to 
Fig. 2 Microscopic images of Botryococcus strains examined. * Race belonging to CCALA 779 is not available. Scale bar $=$ $10 \mu \mathrm{m}$
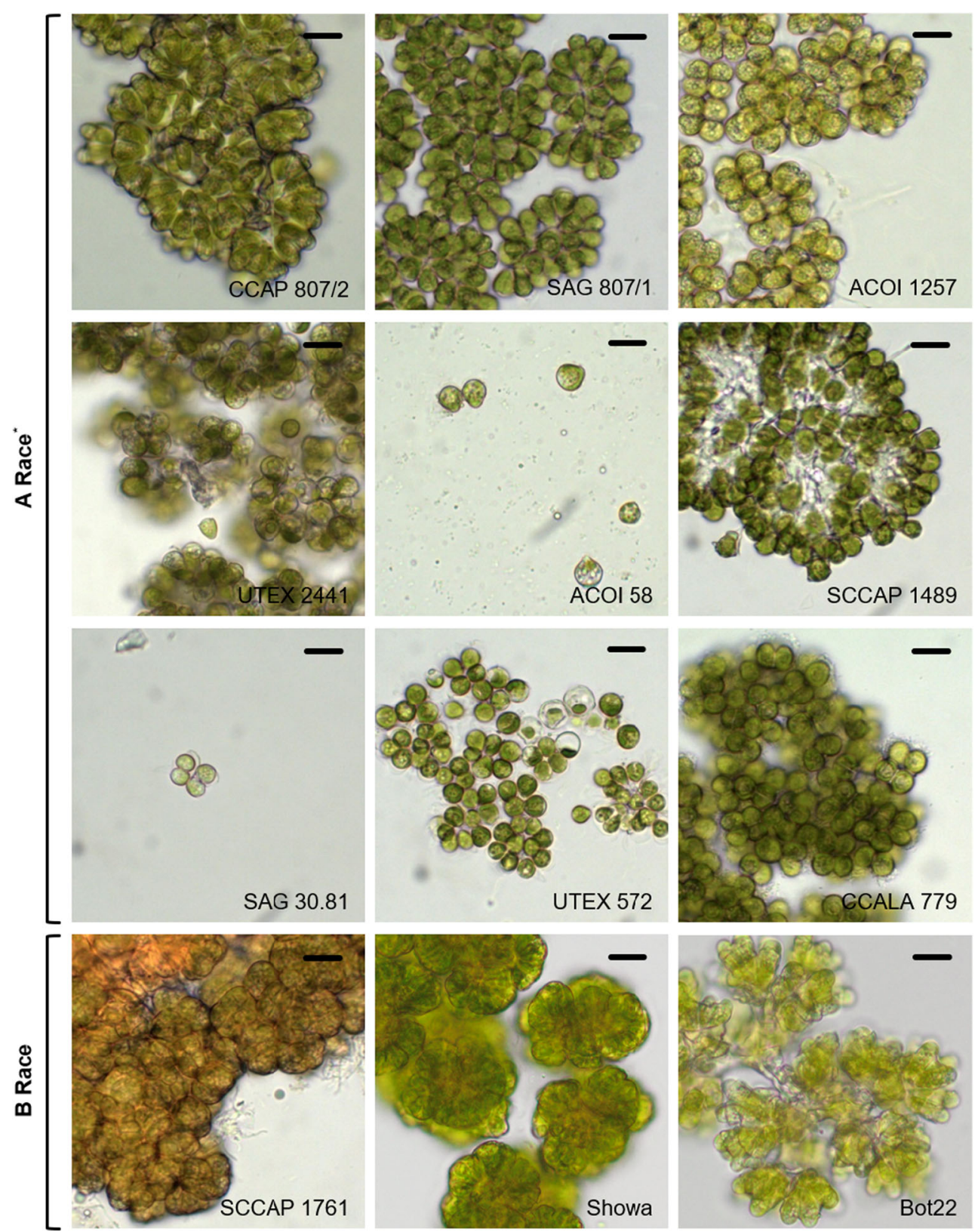

$32.15 \pm 13.14 \%$ for CCAP $807 / 2$ and UTEX 2441, respectively. For $n$-heptane, the highest decrease in oxygen production was observed for the strains UTEX $2441(82.47 \pm 14.17$ to $52.43 \pm 18.25 \%)$, ACOI $58(55.96 \pm 12.15$ to $19.53 \pm 9.64 \%)$, and SAG $807 / 1(80.37 \pm 5.83$ to $61.83 \pm 10.10 \%)$ in response to an increased treatment time. The UTEX 2441 strain was most affected by increasing the contact time with the solvent compared with the other strains, while Showa and Bot22 showed the least influence on oxygen production.

\section{Lipid extractability}

A major criterion for the process of milking is the extractability of hydrocarbons from Botryococcus colonies. In order to determine this extractability, cultures were treated for 5 and 10 min with the solvents $n$-hexane, $n$-heptane, and $n$-octane. As shown in Fig. 6, lipids could be extracted for all strains, solvents, and contact times. Following an increase in extraction time, significantly more lipids could be extracted for all strains (ANOVA, $F(1,70)=2310.075, P<0.001$ ). In this case, the solvent had no significant impact on the amount of lipids extracted (ANOVA, $F(2,33)=0.0109, P=0.989$ ). Highest extractability was measured for the B race strains SCCAP 1761, Showa, and Bot22 with $8.75 \pm 0.075,5.49 \pm$ 0.033 , and $3.55 \pm 0.045 \%$ of extracted lipids per dry weight, respectively. In comparison, only 0.5 to $1.5 \%$ lipids were extracted using A race strains ACOI 1257, CCAP 807/2, SAG 807/2, and UTEX 572. 


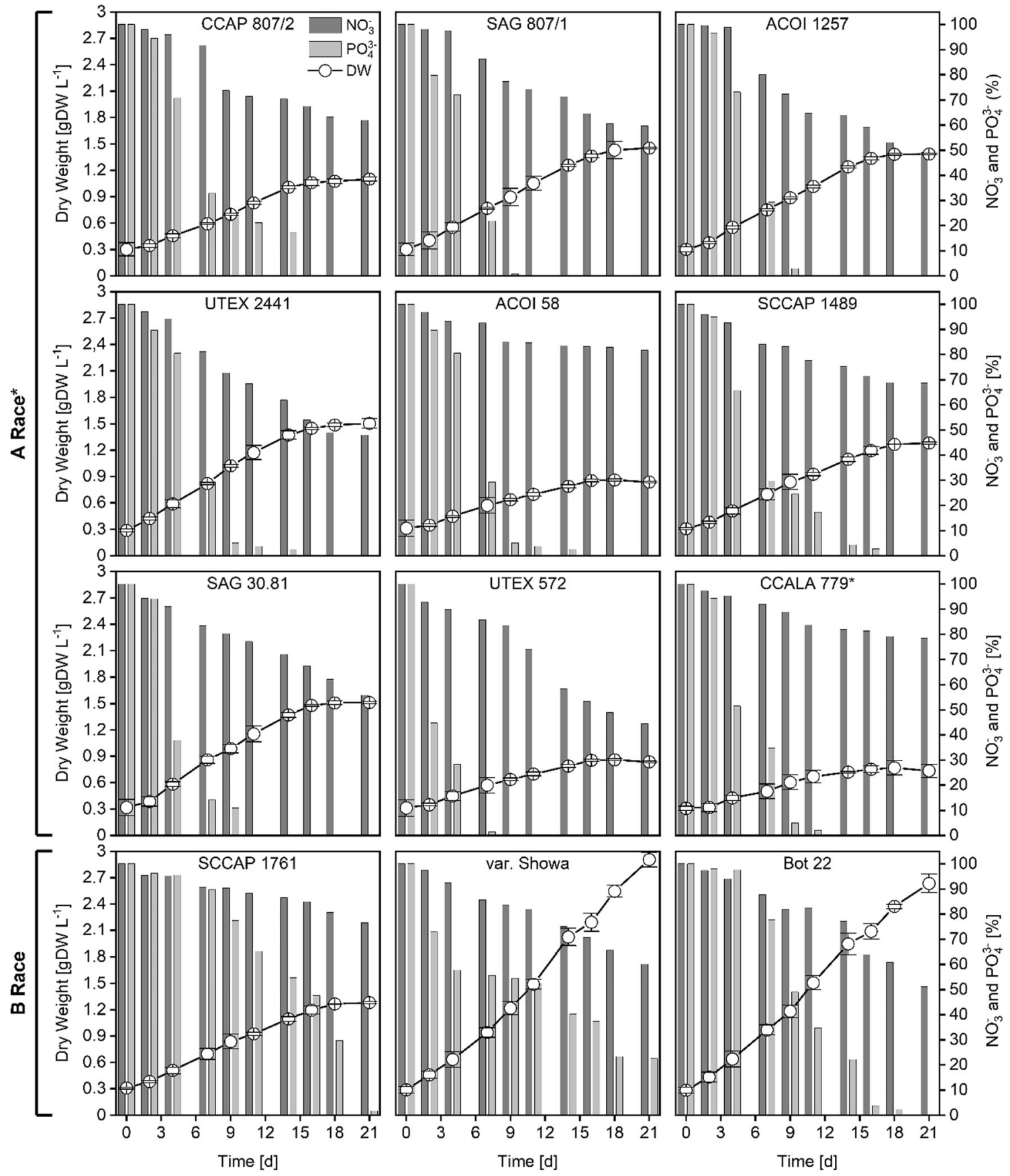

Fig. 3 Growth curves and nutrient consumption (nitrate and phosphate) of Botryococcus strains investigated. *Race belonging to CCALA 779 is not available. Values represent mean $\pm \mathrm{SD}(n=3)$

\section{Ranking of strains}

The overall ranking of Botryococcus strains examined (Table 5) showed that Showa (71 out of 75) and Bot22 (64 out of 75) were the strains most suited for milking. In contrast to a lower concentration for total lipids compared with Showa, Bot22 achieved the highest concentration of extracellular hydrocarbons. The most unsuitable strains for milking seemed to be UTEX 572 with only 22 out of 75 ranking points, followed by CCALA 779 with 25 points.

\section{Discussion}

The growth of Botryococcus braunii is mainly influenced by its specific carbon partitioning during photosynthesis. Compared with other plants and microalgae, which use approximately $85 \%$ of the captured carbon for biomass synthesis, B. braunii uses only $45 \%$ of the assimilated carbon for growth (Melis 2013). Maximum biomass productivity of $0.146 \pm 0.008 \mathrm{~g}_{\mathrm{DW} \mathrm{L}} \mathrm{L}^{-1}$ day $^{-1}$ was measured for the Showa strain in this study. In comparison with other green algae 
cultured in BG11 medium, B. braunii var. Showa has been shown to achieve a lower biomass productivity (Shu et al. 2018). In this study, the biomass productivity of the different B. braunii strains ranged from $0.042 \pm 0.027 \mathrm{~g}_{\mathrm{DW}} \mathrm{L}^{-1}$ day $^{-1}$ for CCALA 779 to $0.146 \pm 0.008 \mathrm{~g}_{\mathrm{DW}} \mathrm{L}^{-1}$ day $^{-1}$ for Showa and was similar to data published elsewhere (Table 6). Published results as well as our own data indicate that the Showa strain seems to achieve the highest biomass productivity.

In comparison with other microalgae, $B$. braunii displayed a low growth rate. However, lipid content with up to $80 \%$ of dry weight for SCCAP 1761 or Showa and an average lipid yield above $57 \%$ of dry weight for the other strains was significantly higher. Other green freshwater microalgae such as Chlorella or Scenedesmus only achieved up to $43 \%$ total lipids (mainly triacylglycerides) of dry weight under stress or limited nitrogen (Arif et al. 2020), while B. braunii produced hydrocarbons in a growth associated manner (Griehl et al. 2015). Lipid productivity of Botryococcus strains used in this study ranged from $0.026 \pm 0.010$ to $0.116 \pm$ $0.001 \mathrm{~g}_{\text {lipids }} \mathrm{L}^{-1}$ day $^{-1}$ for CCALA 779 and Showa, respectively. Other studies published lipid productivities for example for Chlorella sorokiniana of 0.032 to $0.132 \mathrm{~g}_{\text {lipids }} \mathrm{L}^{-1}$ day $^{-1}$ (Shu et al. 2018; Aziz et al. 2020). It becomes apparent that a higher lipid productivity compared with other green algae will not be achieved even though Botryococcus strains have a high lipid content. This makes $B$. braunii unsuitable for producing hydrocarbons using a classical process chain. Hydrocarbon content of B. braunii investigated in this study ranged from $15.3 \pm 0.1$ to $51.6 \pm$ $1.9 \% \mathrm{DW}$, resulting in a hydrocarbon productivity between $5 \pm 1$ and $72 \pm 1 \mathrm{mg} \mathrm{L}^{-1}$ day $^{-1}$. This high variation was also observed by other researchers, where hydrocarbon content ranged from 7 to 60\% (Eroglu et al. 2011; Li et al. 2013; Gouveia et al. 2017). In this study, the two strains Showa and Bot22, classified as race B strains, accumulated $50 \%$ of their dry weight as hydrocarbons, whereas race A strains accumulated on average only $25 \%$ as hydrocarbons. This high hydrocarbon content is reflected by the hydrocarbon productivity. Whereas the race B strains Showa and Bot22 displayed a respective hydrocarbon productivity of $72 \pm 1$ and $68 \pm$ $2 \mathrm{mg} \mathrm{L}^{-1} \mathrm{day}^{-1}$, the average hydrocarbon productivity of the race A strains with $15 \pm 6 \mathrm{mg} \mathrm{L}^{-1}$ day $^{-1}$ was significantly lower (ANOVA, $F(1,9)=160.341, P<0.001$ ). Similar results were achieved by Li et al. (2013) and Gouveia et al. (2017). Looking at results obtained for this study and data published by others, it becomes apparent that especially race B strains accumulate more hydrocarbons compared with race A strains.

Beside the downstream costs for the production of valuable substances from microalgae, costs for nutrient supplementation are also an important factor for the feasibility of the process with 3 to $10 \%$ of the total process costs (Acién et al. 2012). In general, nutrient consumption for the generation of 
Fig. 4 Total lipid content of Botryococcus strains during 21day batch cultivation in $1.5 \mathrm{~L}$ bubble columns. Values represent mean $\pm \mathrm{SD}(n=3)$

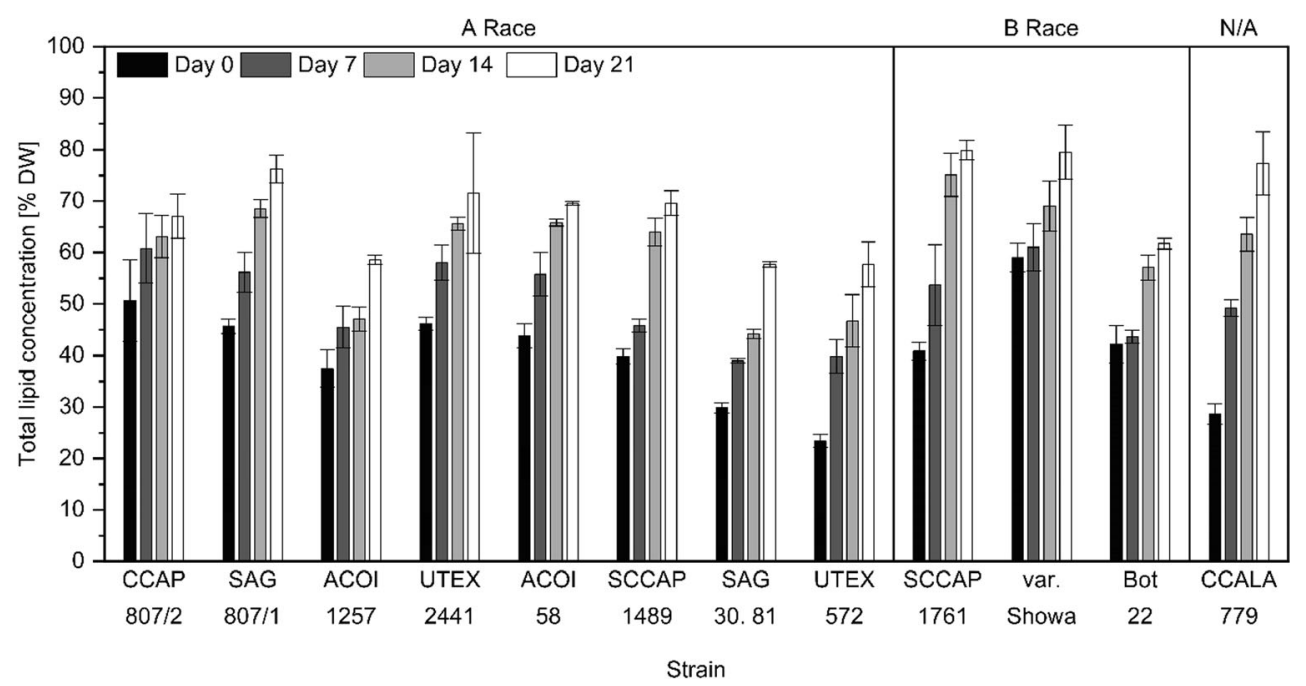

algae biomass could be derived from the stoichiometric formula of Redfield (Redfield 1958) $\mathrm{C}_{106} \mathrm{H}_{263} \mathrm{O}_{110} \mathrm{~N}_{16} \mathrm{P}$. Therewith, $63 \mathrm{mg}$ of nitrogen (280 mg of nitrate) and $9 \mathrm{mg}$ of phosphorus ( $28 \mathrm{mg}$ of phosphate) are required to produce $1 \mathrm{~g}$ of biomass. Considering that this is only a very general value that has been assessed for marine phytoplankton, the actual nutritional uptake for the production of microalgae biomass is strongly influenced by various factors such as temperature, $\mathrm{pH}$, light, $\mathrm{CO}_{2}$, other nutrients, and stressors. Bearing this in mind, data for nutrient uptake presented in this study can only give an indication for the selection of a strain suitable for the process of milking. In this study, nitrate uptake per gram of biomass ranged from $190 \pm 17$ to $931 \pm$ $30 \mathrm{mg}_{\text {nitrate }} \mathrm{g}_{\mathrm{DW}}{ }^{-1}$ for strains Showa and CCAP 807/2, respectively. The average nitrate uptake for all strains was about 497 $\pm 194 \mathrm{mg}_{\text {nitrate }} \mathrm{g}_{\mathrm{DW}}{ }^{-1}$ which is nearly twice as much as the theoretical value. Phosphate uptake ranged from $10 \pm$ $2 \mathrm{mg}_{\text {phosphate }} \mathrm{g}_{\mathrm{DW}}{ }^{-1}$ for Showa to $79 \pm 2 \mathrm{mg}_{\text {phosphate }} \mathrm{g}_{\mathrm{DW}}{ }^{-1}$ for UTEX 572. In this study, the average phosphate uptake for all strains was $38.5 \pm 17 \mathrm{mg}_{\text {phosphate }} \mathrm{g}_{\mathrm{DW}}{ }^{-1}$ and therefore approximately $38 \%$ higher as the expected value of $28 \mathrm{mg}_{\text {phosphate }} \mathrm{g}_{\mathrm{DW}}{ }^{-1}$. These big differences between experimental and theoretical values could not be explained by this data set and need further investigation. However, nutrient uptake was lowest for Showa compared with the other Botryococcus strains in this study indicating its suitability for a scale up and its use for milking.

Another critical parameter for the process of milking is the choice of solvent and thus, the biocompatibility of the selected solvent with the milked strain. Several solvents (dihexyl ether, dodecane, dodecyl acetate, heptane, hexane, octane, $n$-octanol, tetradecane) have been tested for their biocompatibility for

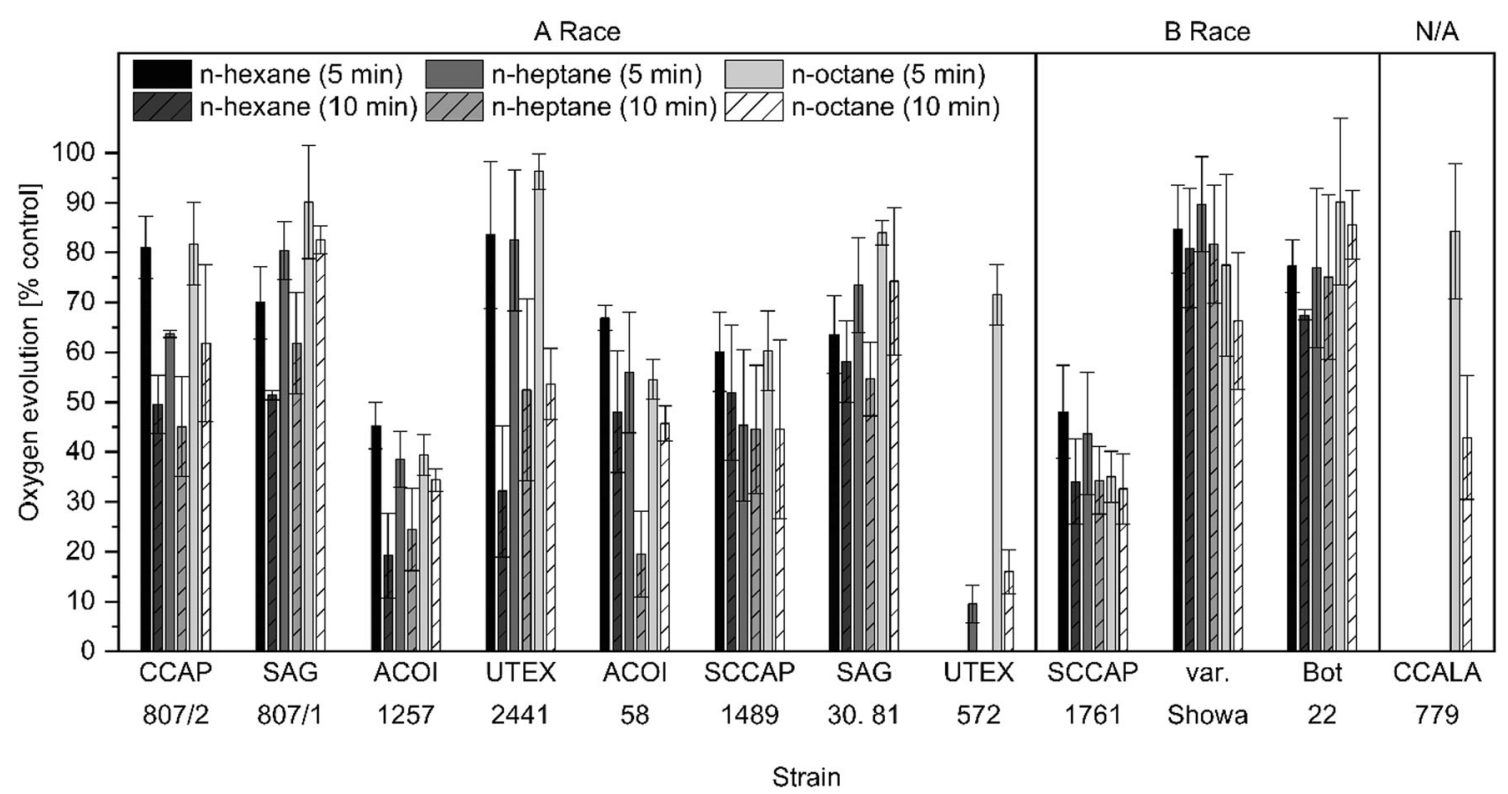

Fig. 5 Oxygen evolution of Botryococcus strains treated with $n$-hexane, $n$-heptane, and $n$-octane. Values represent $\operatorname{mean} \pm \operatorname{SD}(n=3)$ 


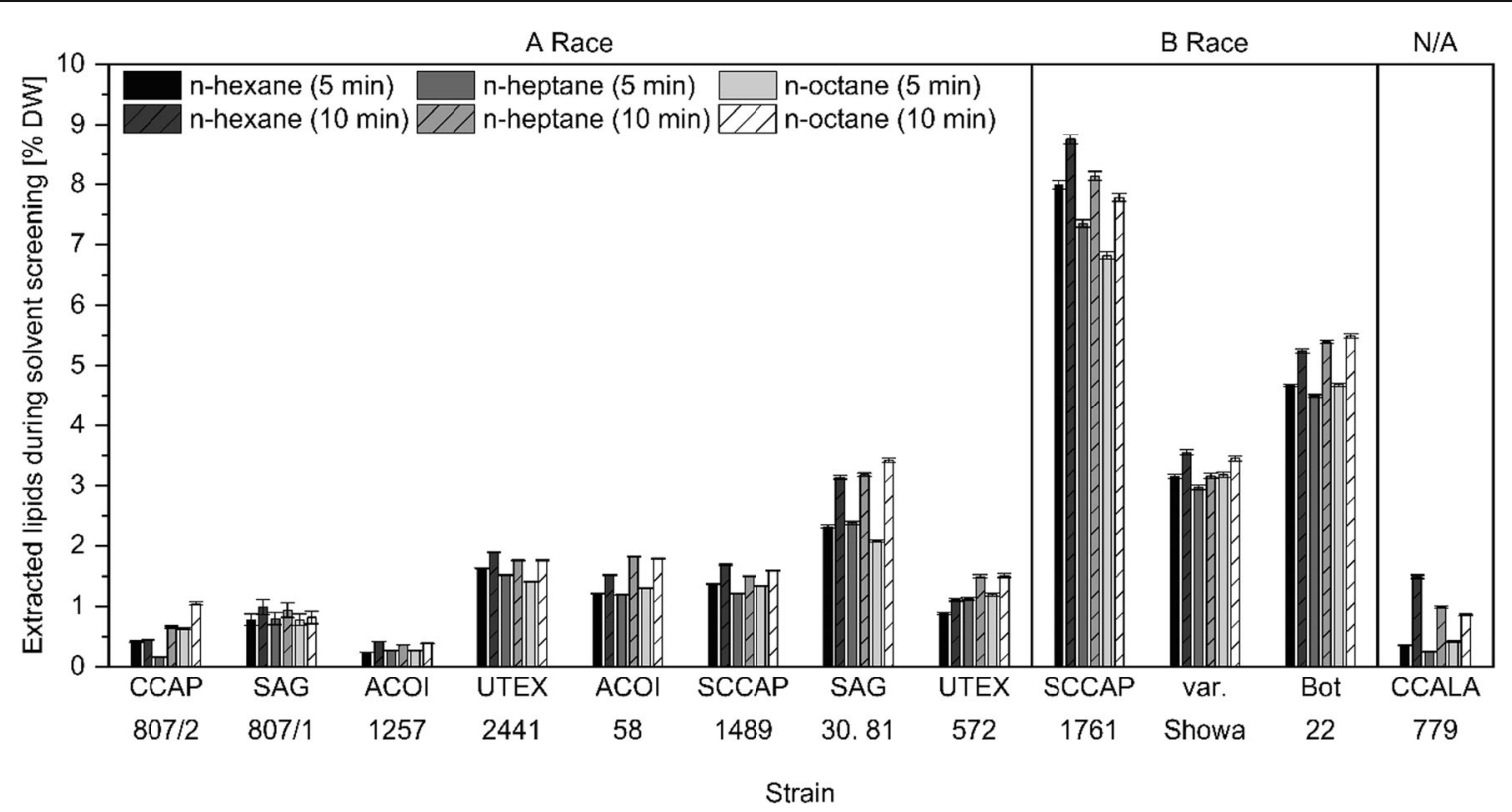

Fig. 6 Concentration of extracted lipids of Botryococcus strains treated for 5 min and 10 min with $n$-hexane, $n$-heptane, and $n$-octane. Values represent mean $\pm \mathrm{SD}(n=3)$

milking B. braunii and summarized by Jackson et al. (2017). In addition to the biocompatibility of a solvent, to which the extraction process could be adapted in terms of contact time (Griehl et al. 2015), the energy required to recover the solvent is becoming increasingly important for transferring the milking process to larger scales. The boiling point of the solvent is the main factor. Jackson et al. (2017) ranked eight previously studied solvents in terms of biocompatibility, boiling point, extraction effectiveness, cost, and safety with the outcome that $n$ hexane is the most suitable solvent with the lowest boiling point, lowest cost, and a high extraction effectiveness, followed by $n$-octane with the highest biocompatibility, but higher recovery costs due to the increased boiling point. Better biocompatibility of $n$-octane compared with $n$-hexane was also observed in this study. Averaging of the results of the strains examined showed that $n$-octane had the highest biocompatibility with over $70 \%$ for the $5 \mathrm{~min}$ and over $50 \%$ for the $10 \mathrm{~min}$ solvent treatment. Solvents $n$-hexane and $n$-heptane were less compatible than $n$-octane averaging $55 \%$ and $40 \%$ for the $5 \mathrm{~min}$ and $10 \mathrm{~min}$ treatments, respectively. This is explained by the fact, that the biocompatibility or toxicity of a solvent is largely determined by the logarithm of the octanol-water partition coefficient $\left(\log \mathrm{P}_{\text {oct }}\right)$. A better biocompatibility of the solvent was found with increasing $\log \mathrm{P}_{\text {oct }}$ value (n-octane $\log \mathrm{P}_{\text {oct }}$ $5.15, n$-heptane $\log \mathrm{P}_{\text {oct }} 4.50, n$-hexane $\log \mathrm{P}_{\text {oct }} 4.00$, from Lide and Frederikse 2004). In terms of solvent compatibility and hydrocarbon extractability, strains Showa and Bot22 showed the best results. In the case of hydrocarbon extractability, this could be explained by the high hydrocarbon content of these two strains compared with the other strains investigated. The
Table 5 Ranking of Botryococcus strains examined

\begin{tabular}{llllllllllll}
\hline Strain & $Y_{\mathrm{DW}}$ & $P_{\mathrm{DW}}$ & $C_{\text {lipids }}$ & $P_{\text {lipids }}$ & $P_{\mathrm{HC}}$ & $C_{\mathrm{HC}}$ & $E_{\mathrm{HC}}$ & $\mathrm{SC}$ & $U_{\text {nitrate }}$ & $U_{\text {phosphate }}$ & Total \\
\hline CCAP 807/2 & 2 & 5 & 3 & 3 & 5 & 3 & 2 & 8 & 1 & 3 & 35 \\
SAG 807/1 & 2 & 7 & 5 & 5 & 2 & 1 & 2 & 9 & 3 & 3 & 39 \\
ACOI 1257 & 2 & 7 & 1 & 3 & 3 & 2 & 1 & 3 & 2 & 3 & 27 \\
UTEX 2441 & 3 & 9 & 4 & 5 & 2 & 1 & 3 & 9 & 3 & 3 & 42 \\
ACOI 58 & 1 & 4 & 3 & 2 & 2 & 2 & 2 & 6 & 3 & 4 & 29 \\
SCCAP 1489 & 2 & 6 & 3 & 4 & 2 & 1 & 2 & 7 & 3 & 4 & 34 \\
SAG 30.81 & 3 & 9 & 1 & 3 & 2 & 1 & 5 & 9 & 4 & 4 & 41 \\
UTEX 572 & 2 & 6 & 1 & 3 & 2 & 1 & 2 & 1 & 2 & 2 & 22 \\
SCCAP 1761 & 2 & 4 & 5 & 3 & 2 & 2 & 10 & 4 & 4 & 3 & 39 \\
Showa & 5 & 10 & 5 & 10 & 10 & 4 & 7 & 10 & 5 & 5 & 71 \\
Bot22 & 5 & 10 & 2 & 8 & 10 & 5 & 6 & 10 & 4 & 4 & 64 \\
CCALA 779 & 1 & 4 & 5 & 2 & 1 & 1 & 2 & 2 & 3 & 4 & 25 \\
\hline
\end{tabular}


Table 6 Biomass and hydrocarbon productivity of various Botryococcus strains compared with the results in this study

\begin{tabular}{|c|c|c|c|c|c|}
\hline Strain & $P_{\mathrm{DW}}\left(\mathrm{g} \mathrm{L}^{-1}\right.$ day $\left.^{-1}\right)$ & $P_{\mathrm{HC}}\left(\mathrm{g} \mathrm{L}^{-1}\right.$ day $\left.^{-1}\right)$ & Reactor type & Cultivation volume (L) & Reference \\
\hline \multirow{5}{*}{$\begin{array}{l}\text { CCAP } \\
807 / 2\end{array}$} & 0.055 & 0.030 & Bubble column & 1.50 & This study \\
\hline & 0.040 & N/A & Carboy & 8.00 & Zhang (2013) \\
\hline & 0.070 & 0.009 & Shake flask & 0.25 & Gouveia et al. (2017) \\
\hline & 0.104 & 0.040 & Carboy & 2.50 & Blifernez-Klassen et al. (2018) \\
\hline & 0.118 & 0.032 & Shake flask & $\mathrm{N} / \mathrm{A}$ & Chaudhari (2016) \\
\hline \multirow{3}{*}{$\begin{array}{l}\text { SAG } \\
807 / 1\end{array}$} & 0.076 & 0.015 & Bubble column & 1.50 & This study \\
\hline & 0.310 & 0.265 & Bubble column & 1.00 & Casadevall et al. (1985) \\
\hline & 0.443 & 0.237 & Flat Panel & 1.00 & Pengfei et al. (2017) \\
\hline \multirow{2}{*}{$\begin{array}{l}\text { ACOI } \\
1257\end{array}$} & 0.076 & 0.019 & Bubble column & 1.50 & This study \\
\hline & 0.020 & 0.007 & Bubble column & 2.00 & Joao et al. (2017) \\
\hline \multirow{2}{*}{$\begin{array}{l}\text { UTEX } \\
2441\end{array}$} & 0.092 & 0.015 & Bubble column & 1.50 & This study \\
\hline & 0.060 & 0.008 & Shake flask & 0.50 & Eroglu et al. (2011) \\
\hline \multirow{2}{*}{$\begin{array}{l}\text { ACOI } \\
58\end{array}$} & 0.044 & 0.029 & Bubble column & 1.50 & This study \\
\hline & 0.015 & 0.003 & Bubble column & 2.00 & Joao et al. (2017) \\
\hline \multirow{2}{*}{$\begin{array}{l}\text { SCCAP } \\
1489\end{array}$} & 0.064 & 0.011 & Bubble column & 1.50 & This study \\
\hline & 0.110 & 0.008 & Shake flask & 0.25 & Gouveia et al. (2017) \\
\hline \multirow{4}{*}{$\begin{array}{l}\text { SAG } \\
30.81\end{array}$} & 0.090 & 0.014 & Bubble column & 1.50 & This study \\
\hline & 0.090 & N/A & Shake flask & 0.25 & Gouveia et al. (2017) \\
\hline & 0.055 & 0.010 & Shake flask & 0.10 & Ranga Rao et al. (2007) \\
\hline & 0.207 & 0.068 & BioFlo Fermentor & 8.00 & Jin et al. (2016) \\
\hline \multirow{4}{*}{$\begin{array}{l}\text { UTEX } \\
572\end{array}$} & 0.067 & 0.011 & Bubble column & 1.50 & This study \\
\hline & 0.079 & 0.013 & Circular pond & 50.00 & Jin et al. (2016) \\
\hline & 0.110 & 0.010 & Shake flask & 0.50 & Eroglu et al. (2011) \\
\hline & 0.110 & $\mathrm{~N} / \mathrm{A}$ & Shake flask & 0.25 & Gouveia et al. (2017) \\
\hline \multirow{4}{*}{$\begin{array}{l}\text { SCCAP } \\
1761 \\
\text { Showa }\end{array}$} & 0.047 & 0.011 & Bubble column & 1.50 & This study \\
\hline & 0.146 & 0.072 & Bubble column & 1.50 & This study \\
\hline & 0.140 & 0.035 & Bubble column & 0.40 & Gouveia et al. (2017) \\
\hline & 0.125 & 0.036 & Shake flask & 0.50 & Eroglu et al. (2011) \\
\hline \multirow[t]{2}{*}{ Bot 22} & 0.132 & 0.068 & Bubble column & 1.50 & This study \\
\hline & 0.080 & 0.046 & Carboy & 10.00 & Mehta et al. (2019) \\
\hline \multirow{2}{*}{$\begin{array}{l}\text { CCALA } \\
779\end{array}$} & 0.042 & 0.007 & Bubble column & 1.50 & This study \\
\hline & 0.080 & 0.008 & Shake flask & 0.25 & Gouveia et al. (2017) \\
\hline
\end{tabular}

high solvent compatibility of Showa and Bot22 could be explained by the extracellular matrix of the colonies surrounding the cells. This matrix consists of liquid hydrocarbons that could be milked and polymerized hydrocarbons that are not soluble (Metzger et al. 2008). Berkaloff et al. (1983) showed that the cell wall of a $B$. braunii race A strain consists of a biopolymer which is resistant to non-oxidative degradation. This resistant biopolymer accounts for $9 \%$ of the cell dry weight and appears together with the hydrocarbons produced (Berkaloff et al. 1983). This leads to the conclusion that with an increased level of deliverable hydrocarbons, measured for the race B strains, the level of polymerized hydrocarbons, which protects the cells, could also be higher compared with the race A strains.
However, good solvent tolerance and hydrocarbon extractability make Botryococcus strains Showa and Bot22 good candidates for the process of milking.

In conclusion, a ranking of the strains investigated with regard to growth, nutrient uptake, lipid and hydrocarbon concentration, solvent compatibility, and lipid extractability can give an indication of the performance of the respective strain during the process of milking. Due to the fact that the displayed results were obtained during batch cultivation, a definite statement about how the various strains perform during the process of milking could be obtained by only milking these strains repeatedly over a longer period of time. Furthermore, the stability of the process, the continuity of hydrocarbon harvest, and the 
feasibility of the milking process for the respective strain could only be assessed by milking over a longer period of time. Nevertheless, the Showa strain, which has not previously been used for repetitive long-term milking, appears to be the best candidate due to its good growth, high lipid content, and solvent compatibility. In addition, it was discovered that nutrient consumption of this strain is the lowest among the strains studied and that it favors the feasibility of the entire process. Strain Bot22 also seems to be very suitable for the process of milking and its performance during long-term milking over 80 days with 16 extraction days, and a lipid yield of $12 \mathrm{mg} \mathrm{L}^{-1}$ day $^{-1}$ has already been demonstrated (Moheimani et al. 2014). For further investigations on the milking process, these two strains should be examined in more detail.

Acknowledgments We would like to thank Prof. Dr. Makoto M. Watanabe from the Algae Biomass and Energy System R\&D Center/ University of Tsukuba for making the Botryococcus braunii strain Bot22 available for us. Furthermore, we thank Prof. Dr. Shigeru Okada from the Faculty and Graduate School of Agriculture and Life Science/ University of Tokyo for providing the Botryococcus braunii strain var. Showa.

Authors' contributions Experiments were planned, conducted, and analyzed by CK. Manuscript was written by CK and reviewed by CG. Funding was realized by CG.

Funding Open Access funding enabled and organized by Projekt DEAL.

Data availability Data are available on request to corresponding author.

\section{Compliance with ethical standards}

Conflict of interest The authors declare that they have no conflict of interest.

Open Access This article is licensed under a Creative Commons Attribution 4.0 International License, which permits use, sharing, adaptation, distribution and reproduction in any medium or format, as long as you give appropriate credit to the original author(s) and the source, provide a link to the Creative Commons licence, and indicate if changes were made. The images or other third party material in this article are included in the article's Creative Commons licence, unless indicated otherwise in a credit line to the material. If material is not included in the article's Creative Commons licence and your intended use is not permitted by statutory regulation or exceeds the permitted use, you will need to obtain permission directly from the copyright holder. To view a copy of this licence, visit http://creativecommons.org/licenses/by/4.0/.

\section{References}

Acién FG, Fernández JM, Magán JJ, Molina E (2012) Production cost of a real microalgae production plant and strategies to reduce it. Biotechnol Adv 30:1344-1353

An JY, Sim SJ, Kim BW, Lee JS (2004) Improvement of hydrocarbon recovery by two-stage cell-recycle extraction in the cultivation of Botryococcus braunii. J Microbiol Biotechnol 14:932-937
Arif M, Bai Y, Usman M, Jalalah M, Harraz FA, Al-Assiri MS, Li X, Salama ES, Zhang C (2020) Highest accumulated microalgal lipids (polar and non-polar) for biodiesel production with advanced wastewater treatment: role of lipidomics. Bioresour Technol 298:122299

Aziz MMA, Kassim KA, Shokravi Z, Jakarni FM, Lieu HY, Zaini N, Tan LS, Islam S, Shokravi H (2020) Two-stage cultivation strategy for simultaneous increases in growth rate and lipid content of microalgae: a review. Renew Sust Energ Rev 119:109621

Berkaloff C, Casadevall E, Largeau C, Metzger SP, Virlet J (1983) The resistant polymer of the walls of the hydrocarbon-rich alga Botryococcus braunii. Phytochemistry 22:389-397

Bhadana B, Tyagi RD (2020) Milking of lipids from oleaginous microorganisms. In: Tyagi RD, Surampalli RY, Zhang TC, Yan S, Zhang $\mathrm{X}$ (eds) Biodiesel production: technologies, challenges, and future prospects. ASCE, Reston, pp 383-396

Blifernez-Klassen O, Chaudhari S, Klassen V, Wördenweber R, Steffens T, Cholewa D, Niehaus K, Kalinowski J, Kruse O (2018) Metabolic survey of Botryococcus braunii: impact of the physiological state on product formation. PLoS One 13:e198976

Borowitzka MA (2013) High-value products from microalgae-their development and commercialisation. J Appl Phycol 25:743-756

Borowitzka MA (2018) Biology of microalgae. In: Levine IA, Fleurence $\mathrm{J}$ (eds) Microalgae in health and disease prevention. Academic Press, London, pp 23-72

Borowitzka MA, Moheimani NR (2013) Sustainable biofuels from algae. Mitig Adapt Strateg Glob Chang 18:13-25

Casadevall E, Dif D, Largeau C, Gudin C, Chaumont D, Desanti O (1985) Studies on batch and continuous cultures of Botryococcus braunii: hydrocarbon production in relation to physiological state, cell ultrastructure, and phosphate nutrition. Biotechnol Bioeng 27: 286-295

Chaudhari S (2016) Systematic metabolic characterization of hydrocarbon and exo-polysaccharide producing microalga Botryococcus braunii. Dissertation, University Bielefeld

Deviram G, Mathimani T, Anto S, Ahamed TS, Ananth DA, Pugazhendhi A (2020) Applications of microalgal and cyanobacterial biomass on a way to safe, cleaner and a sustainable environment. J Clean Prod 253:119770

Eroglu E, Okada S, Melis A (2011) Hydrocarbon productivities in different Botryococcus strains: comparative methods in product quantification. J Appl Phycol 23:763-775

Frenz J, Largeau C, Casadevall E, Kollerup F, Daugulis AJ (1989) Hydrocarbon recovery and biocompatibility of solvents for extraction from cultures of Botryococcus braunii. Biotechnol Bioeng 34: 755-762

Gonçalves AL, Pires JCM, Simões M (2016) Biotechnological potential of Synechocystis salina co-cultures with selected microalgae and cyanobacteria: nutrients removal, biomass and lipid production. Bioresour Technol 200:279-286

Gouveia JD, Ruiz J, van den Broek LAM, Hesselink T, Peters S, Kleinegris DMM, Smith AG, van der Veen D, Barbosa MJ, Wijffels RH (2017) Botryococcus braunii strains compared for biomass productivity, hydrocarbon and carbohydrate content. J Biotechnol 248:77-86

Griehl C, Bieler S (2011) Algen: Rohstoffe für Gesundheit, Schönheit und Energie. Nachr Chem 59:942-947

Griehl C, Kleinert C, Griehl C, Bieler S (2015) Design of a continuous milking bioreactor for non-destructive hydrocarbon extraction from Botryococcus braunii. J Appl Phycol 27:1833-1843

Guckert JB, White DC (1988) Evaluation of a hexane/isopropanol lipid solvent system for analysis of bacterial analysis of bacterial phospholipids and application to chloroform-soluble Nuclepore (polycarbonate) membranes with retained bacteria. J Microbiol Methods 8:131-127 
Hejazi MA, Kleinegris D, Wijffels RH (2004) Mechanism of extraction of $\beta$-carotene from microalga Dunaliellea salina in two-phase bioreactors. Biotechnol Bioeng 88:593-600

Jackson BA, Bahri PA, Moheimani NR (2017) Repetitive nondestructive milking of hydrocarbons from Botryococcus braunii. Renew Sust Energ Rev 79:1229-1240

Jackson BA, Bahri PA, Moheimani NR (2019) Repetitive extraction of botryococcene from Botryococcus braunii: a study of the effects of different solvents and operating conditions. J Appl Phycol 31:34913501

Jackson BA, Bahri PA, Moheimani NR (2020) Non-destructive extraction of lipids from Botryococcus braunii and its potential to reduce pond area and nutrient costs. Algal Res 47:101833

Jin J, Dupré C, Yoneda K, Watanabe MM, Legrand J, Grizeau D (2016) Characteristics of extracellular hydrocarbon-rich microalga Botryococcus braunii for biofuels production: recent advances and opportunities. Process Biochem 51:1866-1875

Joao T, Tiago P, Ricardo M (2017) Evaluation of two Portuguese strains of Botryococcus braunii as biofuel feedstock. Int J Biotechnol Mol Biol Res 8:20-29

Khoo KS, Chew KW, Yew GY, Leong WH, Chai YH, Show PL, Chen WH (2020) Recent advances in downstream processing of microalgae lipid recovery for biofuel production. Bioresour Technol 304:122996

Kleinegris DMM, Janssen M, Brandenburg WA, Wijffels RH (2010) The selectivity of milking of Dunaliella salina. Mar Biotechnol 12:14 23

Li Y, Moore RB, Qin JG, Scott A, Ball AS (2013) Extractable liquid, its energy and hydrocarbon content in the green alga Botryococcus braunii. Biomass Bioenergy 52:103-112

Lide DR, Frederikse HPR (2004) Handbook of chemistry and physics. CRC Press, Boca Raton

Mehta P, Jackson BA, Nwoba EG, Vadiveloo A, Bahri PA, Mathur AS, Moheimani NR (2019) Continuous non-destructive hydrocarbon extraction from Botryococcus braunii BOT-22. Algal Res 41: 101537

Melis A (2013) Carbon partitioning in photosynthesis. Curr Opin Chem Biol 17:453-456

Metzger P, Largeau C (2005) Botryococcus braunii: a rich source for hydrocarbons and related ether lipids. Appl Microbiol Biotechnol 66:486-496

Metzger P, Rager MN, Fosse C (2008) Braunicetals: acetals from condensation of macrocyclic aldehydes and terpene diols in Botryococcus braunii. Phytochemistry 69:2380-2386

Moheimani NR, Cord-Ruwisch R, Raes E, Borowitzka MA (2013) Nondestructive oil extraction from Botryococcus braunii (Chlorophyta). J Appl Phycol 25:1653-1661

Moheimani NR, Matsuura H, Watanabe MM, Borowitzka MA (2014) Non-destructive hydrocarbon extraction from Botryococcus braunii BOT-22 (race B). J Appl Phycol 26:1453-1463
Pengfei C, Yan W, Qiyong Y, Tianzhong L (2017) Comparison of growth, hydrocarbon accumulation and metabolites of Botryococcus braunii between attached cultivation and aqueoussuspension cultivation. Int J Agric Biol Eng 10:134-141

Praveenkumar R, Gwak R, Kang M, Shim TS, Cho S, Lee J, Oh YK, Lee K, Kim B (2015) Regenerative astaxanthin extraction from a single microalgal (Haematococcus pluvialis) cell using a gold nano-scalpel. ACS Appl Mater Interface 7:22702-22708

Ranga Rao A, Sarada R, Ravishankar GA (2007) Influence of $\mathrm{CO}_{2}$ on growth and hydrocarbon production in Botryococcus braunii. J Microbiol Biotechnol 17:414-419

Redfield AC (1958) The biological control of chemical factors in the environment. Am Sci 46:230A-2221A

Rippka R, Deruelles J, Waterbury JB, Herdman M, Stanier RY (1979) Generic assignments, strain histories and properties of pure cultures of cyanobacteria. J Gen Microbiol 11:1-61

Rosello Sastre R, Posten C (2010) The variety of microalgae applications as a renewable resource. Chemie-Ingenieur-Technik 82:1925-1939

Samori C, Pezzolesi L, Gallette P, Semerarao M, Taliavini E (2019) Extraction and milking of astaxanthin from Haematococcus pluvialis cultures. Green Chem 21:3621-3628

Santhosh S, Dhandapani R, Hemalatha N (2016) Bioactive compounds from microalgae and its different applications-a review. Pelagia Res Libr Adv Appl Sci Res 7:153-158

Shu Q, Qin L, Yuan Z, Zhu S, Xu J, Xu Z, Feng P, Wang Z (2018) Comparison of dairy wastewater and synthetic medium for biofuels production by microalgae cultivation. Energy Sources A 40:751-758

Sim SJ, An JY, Kim BW (2001) Two-phase extraction culture of Botryococcus braunii producing long-chain unsaturated hydrocarbons. Biotechnol Lett 23:201-205

Tjørve KMC, Tjørve E (2017) The use of Gompertz models in growth analyses, and new Gompertz-model approach: an addition to the unified-Richards family. PLoS One 12:e0178691

Vinayak V, Manoylov KM, Gateau H, Blanckaert V, Hérault J, Pencréac'h G, Marchand J, Gordon R, Schoefs B (2015) Diatom milking? A review and new approaches. Mar Drugs 13:2629-2665

Zhang J (2013) Culture of Botryococcus braunii. Masters Thesis. Murdoch University

Zhang F, Cheng LH, Xu XH, Zhang L, Chen HL (2011) Screening of biocompatible organic solvents for enhancement of lipid milking from Nannochloropsis sp. Process Biochem 46:1934-1941

Zhang F, Cheng LH, Xu XH, Zhang L, Chen HL (2013) Application of memberane dispersion for enhanced lipid milking from Botryococcus braunii FACHB 357. J Biotechnol 165:22-29

Publisher's note Springer Nature remains neutral with regard to jurisdictional claims in published maps and institutional affiliations. 